\title{
Social Sustainability: A Review of Indicators and Empirical Application
}

\author{
Gideon Baffoe (Corresponding author) \\ Graduate Program in Sustainability Science-Global Leadership Initiative \\ Graduate School of Frontier Sciences, The University of Tokyo \\ Room 485, Environmental Studies Building \\ 5-1-5 Kashiwanoha, Kashiwa City, Chiba, 277-8563, Japan
}

Tel: 82-80-6250-2398 E-mail: gideonbaffoe@ @ustainability.k.u-tokyo.ac.jp

Emmanuel Mutisya

Graduate Program in Sustainability Science-Global Leadership Initiative

Graduate School of Frontier Sciences, The University of Tokyo

Room 171 Environmental Studies Building

5-1-5 Kashiwanoha, Kashiwa City, Chiba, 277-8563, Jappan

Tel: 81-80-3455-0619Ｅ-mail:emmanuel@sustainability.k.u-tokyo.ac.jp

Received: October 9, 2015 Accepted: October 28, 2015

doi:10.5296/emsd.v4i2.8399 URL: http://dx.doi.org/10.5296/emsd.v4i2.8399

\begin{abstract}
As one of the three pillars of sustainable development, social sustainability has received little attention compared to the economic and environmental pillars. The major reason accounting for the neglect is attributed to its contested nature. This has culminated in the current conceptual understanding of the term. Previous efforts on social sustainability have concentrated on theoretical interpretations rather than quantification assessment. This is because quantifying social sustainability is regarded a daunting task. Meanwhile, indicators are disparate which makes understanding even more confusing. To enrich our knowledge on the term, definitional assessment and indicator synthesis and application will play a major role. This study aims to fill the quantification gap. The specific objective of this paper is to
\end{abstract}


review the indicators of social sustainability and empirically apply them using the composite index approach. The review uniquely identified three dimensions (sub components) of social sustainability - representation mechanism, collective state and individual access. Empirical application in Kibera in Kenya, depicted a medium level of social sustainability. The highest contributing sub component was collective state with the least being representation mechanism. The study results evidently suggest policy support for inclusive governance, improved housing, job creation, security, education and community trust. It is believed that addressing these diverse issues will enhance social sustainability in Kibera. The study recommends validation of the current approach using other methods such as Fuzzy Logic or Analytic Hierarchy Process (AHP).

Keywords: Social sustainability, Kibera slum, Composite index, Indicators

\section{Introduction}

The concept of sustainable development has become a household name as evident by the massive proliferation of literature on the subject for the past three decades. This phenomenon could be attributed to the urgency of mankind to save planet earth from unacceptable anthropogenic activities (such as pollution and hyper-consumption of natural resources) which threatens the living environment. The result of recent literature emergence has been the 'competing and conflicting views over the meanings of the terms; what is to be sustained, by whom, for whom, and what is the most desirable means of achieving this goal' (Agyemang and Evans 2004). It is therefore not surprising that the term currently remains a major policy challenge (Spangenberg and Oman 2002).

The most widely known definition of the concept sustainable development is given by the Bruntland Commission. According to the commission, "Sustainable development is development that meets the needs of the present without compromising the ability of future generations to meet their own needs" (WCED 1987a: 43). Agyemang et al. (2003) provide a definition of sustainability as "the need to ensure a better quality of life for all, now and into the future, in a just and equitable manner, whilst living within the limits of supporting ecosystems"'. From ecological perspective, sustainability is defined as the ability of a system to bounce back from shocks and stresses (Scoones 2007). A critical look at the above definitions of sustainable development and sustainability reveals a close linkage which emphasizes the inseparable nature of the terms.

Generally, the three dimensions of sustainable development; economic, environmental and social are referred to as the pillars of development or sustainability (Bostrom 2012). The connections among these pillars are assumed to be compatible and mutually supportive (Costanza et al. 1992; Littig and Grießler, 2005; Huzayyin et al. 2013; Paz et al. 2013; Maheshwari et al. 2014). To avoid semantic confusion in this paper, the term sustainability instead of development is used. Achieving a balance among the pillars can be thought of as sustainable development. But variations with respect to research attention do exist among the pillars. Particularly, the associated meanings and objectives of the social pillar are not well understood (Dempsey et al. 2011; Casula Vifell and Soneryd, 2012). Specifically, the pillar has received little attention. This is partly due to the contested nature of the concept (Dobson 
1999; Agyeman et al. 2003; Agyeman \& Evans, 2004; Lehtonen, 2004; Agyeman, 2008; Cuthill, 2009; Dillard et al. 2009) and the issues that the pillar addresses (Dixon \& Colantonio, 2008). In the meantime recent achievement in social sustainability discourse has been reported in the areas of fair trade certification (e.g., Taylor, 2004), urban and regional planning (Schlossberg and Zimmerman, 2003; Cuthill, 2009; Davidson, 2009; Dempsey et al. 2011), organic agriculture (e.g., Shreck et al. 2006), forest certification (e.g., Klooster, 2010; Boström, 2011), and conventional agriculture (Nordström Källström and Ljung, 2005; Mancini et al. 2008). OECD (2001b, a) has pointed out that the concept is best captured only when assessing the social implications of environmental issues, but not as an equally important aspect of sustainable development. In essence, the needed recognition by scientists and policy makers is not the best (Spangenberg 2002). Current understanding of the term is mainly conceptually. Notably, quantification assessment is lacking.

Quantification assessment of social sustainability is regarded a daunting challenge and approach to it still needs further work. Miller (2007) described criteria for selecting indicators of sustainable development but did not provide a methodology for measuring the indicators especially for the social dimension. Likewise, Axelsson et al (2013) produced visualization map for social sustainability indicators, but made no provision on how to quantify the indicators. According to Spangenberg (2002), for social sustainability to be placed on the same scale as the other pillars of sustainable development, there is the need for clear social targets. This makes indicator setting and measurement an indispensable task in social development processes.

This paper aims to contribute to social sustainability discourse by filling the quantification gap. It reviews the indicators of social sustainability and empirically applies them using the composite index approach. It is believed that the quantification assessment will offer better and practical insight of the concept and allow for evidenced based interventions.

Section 2 deals with the methodology including the quantification approach. Section 3 presents the empirical application results. Section 4 provides the discussion while Section 5 concludes the study.

\subsection{Theoretical Framework}

Social sustainability, as already pointed out, is a contested concept. The origin can be traced to the Bruntland Commission Report (WCED 1987). The commission's report placed much emphasis on social issues such as health and income dichotomy between the rich and the poor. A dictionary definition relates the term social to "human society, the interaction of the individual and the group, or the welfare of human beings as members of society" (Merriam Webster 2012).

Several contextual interpretations have been given by different scholars. Social sustainability is thought of as equity in resource distribution. From livelihood perspective, it is regarded as the capacity of man not only to get access but also to maintain an adequate and decent livelihood (Chambers and Conway 1991). Further, Chambers and Conway mentioned two dimensions of the latter definition; positive and negative. They explained that the negative 
aspect is reactive in that it highlights shocks and stresses coping ability while the positive dimension is proactive due to the fact that it emphasizes the enhancement and exercise of capabilities in adapting to, exploiting and creating change and in assuring continuity.

Likewise, Bostrom (2012) also highlighted two aspects of social sustainability; procedural and substantive. The procedural according Bostrom has to do with the role of democratic representation, participation, and deliberation while, the substantive aspect comprises "what" is to be done (i.e. the social goals of sustainable development). The procedural aspect Bostrom explained captures "how" or the means to achieve the social goals. To Bostrom, social sustainability is all about human welfare including quality of life, social justice, social cohesion, cultural diversity, democratic rights, gender issues, human rights, participation, social capital development and human capability (Bostrom 2012).

Spangenberg (2002b) asserts that social sustainability focuses on personal assets such as education, skills, experience, consumption, income, employment and the right to actively participate in societal activities. The right according to Spangenberg can be ensured by having access to specific societal resources in the shape of physical, legal and economic resources. Access to physical resources as Spangenberg explained requires the existence of appropriate technical, social and institutional infrastructure while the legal access affords the right to utilize the physical resources. Economic access on the other hand explains the affordability of using the various resources (Spangenberg 2002b). Similarly, Cuthill (2009) using action research approach developed a social sustainability framework that includes; social justice and equity, social infrastructure, governance, and social capital. The above interpretations can be summed up using Magis and Shinn's (2009) four universal principles of social sustainability: human well-being, equity, democratic government, and democratic civil society.

From above, it is clear that social sustainability defies single definition. What one society considers crucial to their welfare might differ from another, even in the same region. This means that any attempt to assess social sustainability at any level has to put particular emphasis on the prevailing contextual conditions and preferences of the people. It is only when this is done that one can confidently relate the results to the realities on the ground.

\subsection{Indicators of Social Sustainability}

Measuring social sustainability is a daunting challenge. This is because the concept has diverse dimensions of which some are not easily quantifiable. Using indicators could be one way of bypassing this constraint. Miller (2007) defined indicator as "anything that gives an indication to its reader of a key feature or the state of a human or environmental system". Miller adds that a good indicator has the characteristic of providing valuable information critical for decision making purposes. Thus, indicators can be a good proxy to capture most unquantifiable aspect of social sustainability. Indicators of sustainability take the form of quantitative measures of the key features of human or environmental systems that relate to the long-term viability of human communities (Miller 2007). The divergent and contradictory desires of man have made the use of indicators the best alternative to access complex issues of life (Miller 2004). 


\section{Mll Macrothink}

Here, scholarly papers/articles are reviewed to select key indicators that reflect the social sustainability aspect of sustainable development. Reviewing scholarly work allows the development of a set of indicators that are representative and relevant for decision making purposes (Alexsson et al 2013). Of course, we do not claim that this approach is the only method. This is because there are other approaches, which are thought to be far more representative and relevant. A typical example is the participatory approach where stakeholders are involved in deciding on a set of indicators deemed relevant to their situation. Cuthill (2009) and Alexsson et al. (2013) used this approach in their study.

Literature on social concerns deemed important for policy consideration abounds. Mention could be made to social indicators (UNCSD, 1996; UNDESA, 2001); social realm (Chan \& Lee, 2008), social themes (UNDESA, 2001); democracy and equity (Rothstein and Uslaner 2005; Magis and Shinn 2009); human development (Magis and Shinn 2009) and social sustainability (Goodland, 2002; Turkington \& Sangster, 2006; Chan \& Lee, 2008). For the purposes of this paper, we limit ourselves to the factors that represent social sustainability in a more realistic manner. Based on our review so far, we categorize the indicators under three dimensions; representation mechanism, collective state and individual access. Table 1 shows the three sub components of social sustainability and the scholarly references.

Table 1. The dimensions of social sustainability

\begin{tabular}{|c|c|c|}
\hline Category & Indicators & Scholarly reference \\
\hline $\begin{array}{l}\text { 1. Representation } \\
\text { mechanism }\end{array}$ & $\begin{array}{l}\text { Participation in } \\
\text { decision making } \\
\text { process } \\
\text { Grass root } \\
\text { development } \\
\text { initiatives }\end{array}$ & $\begin{array}{l}\text { Hans-Boeckler-Foundation 2001; Littig 2001; Spangenberg 2002b; } \\
\text { Rothstein and Uslaner 2005; Cuthill 2009; Murphy 2012; Bostrom } \\
2012\end{array}$ \\
\hline 2. Collective state & $\begin{array}{l}\text { Group membership } \\
\text { Trust } \\
\text { Family ties } \\
\text { Crime free } \\
\text { environment } \\
\end{array}$ & $\begin{array}{l}\text { Hans-Boeckler-Foundation 2001; Cuthill 2009; Murphy 2012; } \\
\text { Bostrom } 2012\end{array}$ \\
\hline $\begin{array}{l}3 . \quad \text { Individual } \\
\text { access }\end{array}$ & $\begin{array}{l}\text { Education } \\
\text { Health care } \\
\text { Job } \\
\text { Better housing } \\
\text { Food }\end{array}$ & $\begin{array}{l}\text { UNDESA 2001; Rothstein and Uslaner 2005; Chan and Lee } \\
\text { (2008), Cuthill 2009 Cuthill 2009; Magis and Shinn 2009; Murphy } \\
\text { 2012; Bostrom 2012; Chen et al. } 2013\end{array}$ \\
\hline
\end{tabular}

\section{Methodology}

\subsection{Study Area}

Kibera in Nairobi is one of the biggest informal settlements in Africa and largest in Kenya (Kibera UK 2007; Kaiganaine 2009). The population is estimated to be around 1 Million people with land ownership vested solely in the hands of the government (Kibera UK 2007). 


\section{Macrothink}

Environmental Management and Sustainable Development

ISSN 2164-7682

2015, Vol. 4, No. 2

Inhabitants in Kibera are mostly tenants and young migrants seeking to make a better life in the city (Cronin and Gutherie 2011).

The area is characterised by widespread unemployment with rate around (80\%) (People of Kibera, 2010). Again, Kibera lacks access to portable water, sanitation and good roads. Food prices are volatile as a result of drought, floods, famine and political unrest (ReliefWeb, 2010). Medical care is given by charitable organisations such as Amref Africa, Médecins Sans Frontières (MSF), churches among others (Kibera UK 2007). More recently, the government of Kenya has started a major informal settlement resettlement plan - Kenya Slum Upgrading Program (KENSUP) with the objective to build new houses to replace the dilapidated structures in urban areas. However, the project is observed to be flouted with lots of challenges e.g. mistrust in allocation of flats, unreliable supply of water and electricity among others (Higgins 2013). Nevertheless, the low cost of living makes Kibera home for low income urban residents despite the unfavourable living conditions (Higgins 2013). The above-enumerated characteristics make Kibera an ideal place for the social sustainability assessment.

\subsection{Data Collection}

The study was conducted in four communities (Makina, Laini Saba, Gatwekera and Kianda) out of the 12 communities that form Kibera as shown in Figure 1. The selection of the communities was random paying particular attention to the spatial distribution. Household questionnaire survey, participant observation and key informant interviews were the methods used to collect the data. A total of 100 questionnaires were randomly administered in the four communities ( 25 questionnaires in each community). The questionnaire sought to collect data on socio-demographic characteristics and asset access situation of the households. In addition, observation and key informant interviews were used to triangulate the data. 


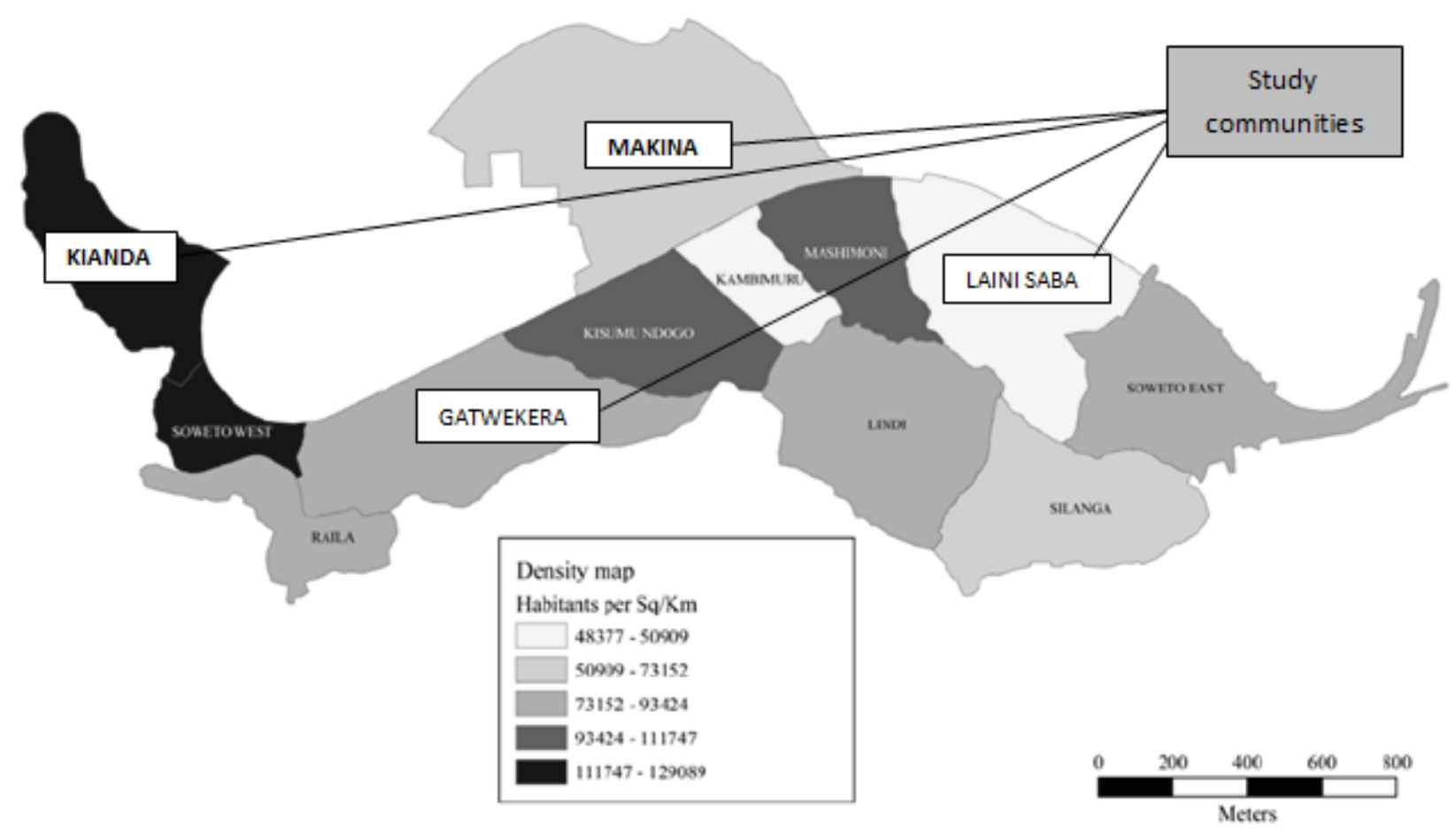

Figure 1. Map of Kibera showing the twelve communities and the study areas (marked with white rectangular box)

Source: IFRA-Keyobs, 2009

\subsection{Measurement Design}

Three dimensions of social sustainability have been designed and presented in Table 1 . This study uses various scaling and indexing method to make them comparable in order to afford a better understanding just like what Chen et al. (2013) did in their paper. It should however be noted that the paper of Chen et al. (2013) was not about social sustainability but on livelihood assets. The authors used the method to develop index for livelihood assets comprising of the five livelihood capitals (social, human, financial, physical and natural capital). The study uses three plotting techniques for the weighting. This paper only adopts their approach here to analyze the social sustainability. Following Chen et al. (2013), the indicators will be determined by rating scale methods. For weightings, indices of "0-0.33", "0.34-0.66" and 0.67-1" will be interpreted as "Low", "Medium" and "High" respectively. We again set three key values; $0.33,0.66$ and 1 to represent Low, Medium and High respectively. The final social sustainability index score will be interpreted using these categories (Low, Medium and High). The study plots the weightings using the first two methods by Chen et al. (2013).

The first is the choice questions; Poor, Average and Good for variables such as health and educational status;

$\mathrm{I}=\operatorname{Good} \% \times 1+$ Average $\% \times 0.66+$ Poor $\% \times 0.33$

The second is the "Yes" and "No" questions. 


\section{$\mathrm{I}=\mathrm{Yes} \% \times 1+\mathrm{No} \% \times 0$}

The value for each dimension will be calculated first. The composite index for social sustainability will be calculated using the following equation;

$$
S=\sum_{i=0}^{i} \frac{L i}{N i}
$$

Where $\mathrm{S}$ is the criteria score for each dimension $(0 \leq \mathrm{S} \leq 1)$, $i$ represents $i$ th indicator of criteria $(i=1,2,3, \ldots n) ; L$ represents indicator; $N$ represents the total number of indicators; $\mathrm{SS}=(\mathrm{Rm}+\mathrm{Cs}+\mathrm{Ia}) / 3$ where SS is Social Sustainability; Rm, Cs and Ia are the various dimensions of social sustainability; Rm represents Representative mechanism; Cs represents Collective state and Ia represents Individual access.

We do not claim that this is the only method that can be used for the assessment as there are other equally good approaches such as Fuzzy Logic and Analytic Hierarchy Process (AHP) which can serve same purpose.

\section{Results}

The objective of this paper was to review the indicators of social sustainability and empirically test them using composite index approach.

\subsection{Socio-Demographic Characteristics}

Table 2 presents the socio-demographic characteristics of the respondents. Male respondents comprise $63 \%$ compared to female respondents who form $37 \%$. Fifty five percent are married while $31 \%$ are divorced. In terms of age, $67 \%$ of the respondents are less than 35 years. Meanwhile, $20 \%$ are aged between $35-44$ years. With respect to education, $37 \%$ have secondary education, $18 \%$ - technical/vocational education, $16 \%$ - primary education while only $3 \%$ are illiterate. Also, $16 \%$ of the respondents have stayed in Kibera for less than 5 years compared to $43 \%$ who have stayed there for more than 15 years.

Table 2. Socio-demographic characteristics of respondents

\begin{tabular}{|l|l|}
\hline Characteristic & Percentage $(\%)$ \\
\hline Gender & \\
\hline Male & 63 \\
\hline Female & 37 \\
\hline & \\
\hline Marital status & \\
\hline Married & 55 \\
\hline Single & 9 \\
\hline Widow & 3 \\
\hline
\end{tabular}




\begin{tabular}{|l|l|}
\hline Divorced & 31 \\
\hline Other & 2 \\
\hline & \\
\hline Age (years) & \\
\hline$<35$ & 67 \\
\hline $35-44$ & 20 \\
\hline $45-54$ & 7 \\
\hline $55+$ & 6 \\
\hline & \\
\hline Education & \\
\hline Primary & 16 \\
\hline Middle school & 8 \\
\hline Secondary & 37 \\
\hline Tech/Voc. & 18 \\
\hline Tertiary & 13 \\
\hline Dropout & 5 \\
\hline No education & 3 \\
\hline & \\
\hline Residence (years) & \\
\hline$<5$ & 16 \\
\hline $5-9$ & 23 \\
\hline $10-14$ & 18 \\
\hline $15+$ & 43 \\
\hline & \\
\hline & \\
\hline & \\
\hline & \\
\hline & \\
\hline & \\
\hline
\end{tabular}

Source: Field survey 2015

\subsection{Empirical Computation}

Table 3 shows the computational result of the different sub components of social sustainability. From the table, the overall social sustainability level in Kibera can be described as medium since the final score falls within the $0.34-0.66$ threshold. Collective state happens to be the sub component with the highest score of 0.49 followed by individual access (0.41) and then representation mechanism with a score of 0.38. Even though variations exist among the different sub component scores, they all seem to have medium influence on the social sustainability score. Nonetheless, individual indicators make strong impression. Family ties and group membership under collective state sub component recorded the highest score. This is followed by food availability and healthcare access under individual access. Meanwhile, crime free environment, better housing, job availability and participation in decision making processes in that order are the indicators with least scores. The latter result explanation is consistent with personal observation and speculations circulating around in and outside Nairobi. 
Table 3. Components of social sustainability

\begin{tabular}{|c|c|c|c|}
\hline Dimension & Indicators & $\begin{array}{l}\text { Indicator } \\
\text { weight }\end{array}$ & $\begin{array}{l}\text { Indicator } \\
\text { value }\end{array}$ \\
\hline \multirow[t]{2}{*}{$\begin{array}{l}\text { Representation } \\
\text { mechanism }\end{array}$} & $\begin{array}{l}\text { Participation in decision } \\
\text { making }\end{array}$ & 0.31 & 0.38 \\
\hline & $\begin{array}{ll}\text { Grassroots } & \text { development } \\
\text { initiatives } & \end{array}$ & 0.44 & \\
\hline \multirow[t]{4}{*}{ Collective state } & Group membership & 0.7 & 0.49 \\
\hline & Trust & 0.38 & \\
\hline & Family ties & 0.71 & \\
\hline & Crime-free environment & 0.17 & \\
\hline \multirow[t]{5}{*}{ Individual access } & Education & 0.46 & 0.41 \\
\hline & Healthcare & 0.52 & \\
\hline & Job & 0.25 & \\
\hline & Better housing & 0.18 & \\
\hline & Food & 0.66 & \\
\hline Social sustainability & & & 0.43 \\
\hline
\end{tabular}

Source: Field survey 2015

\section{Discussion}

\subsection{Representation Mechanism}

This result (Figure 1) indicates that representation in Kibera leaves much to be desired. Clearly, people in Kibera lack voice in development process particularly in governance. This result has implication on project/program formulation and implementation. Projects and programs are likely to be implemented without prior consent of the people. A typical example 


\section{Macrothink}

is the KENSUP project which is considered a waste of resources by the residents. This project has been observed to be bedevilled with transparency and accountability issues (Higgins 2013). Interview with the people revealed that the project formulation and implementation took the top-down approach.

But local development initiatives participation is gradually growing in Kibera. This result is a true reflection on the ground. In recent, the people of Kibera have come to the realization that the solutions to the informal settlements will come from the residents, an ideology that has engendered ingenuity in the community. Reference to this can be made to a number of indigenous organisations such as the numerous local NGO's and entrepreneurial groups (e.g. Umande Trust, Victories Brothers and Taka Ni Pato (waste to cash) among others. These groups aim to turn Kibera's problems into business opportunities, leading to the creation of jobs for the people especially the youth. Victories Brothers (Plate 1) for instance uses bones to make handicrafts for both domestic and international markets. The group is motivated by the spirit of self-help and self-development. Similarly, Umande Trust, a formal local NGO is actively engaged in numerous environmental programs aimed at making Kibera an environmentally sound community. A typical example is the bio-centre and community cooker (Plate 2) projects. The bio-centres collect human waste and convert it to energy for cooking. Currently, Umande Trust is operating more than fifty-two bio-centres aimed at improving access to decent and affordable sanitation, income generation opportunities and access to information to community-based enterprises (Umande Trust, 2014). Clearly, while policy has to give voice to the people in order to improve governance, participation in the local development initiatives is in the right direction and has to be supported by all stakeholders.

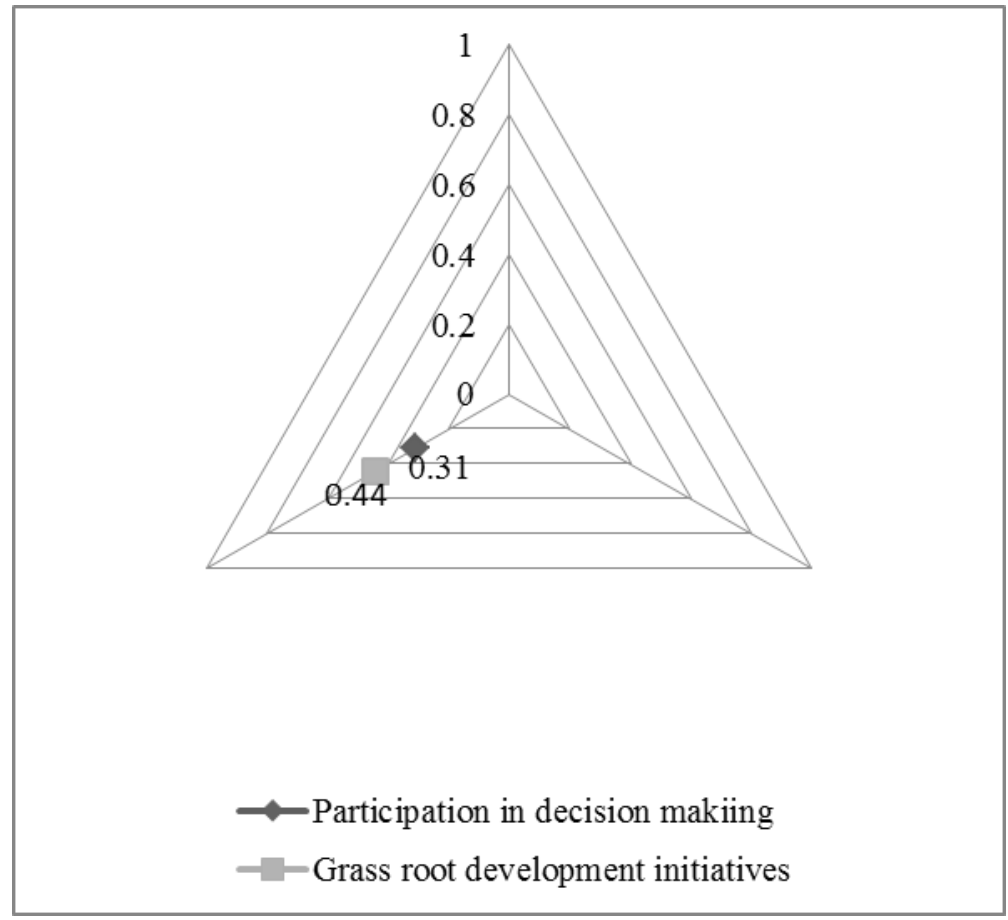

Figure 2. Representation mechanism of people in Kibera 


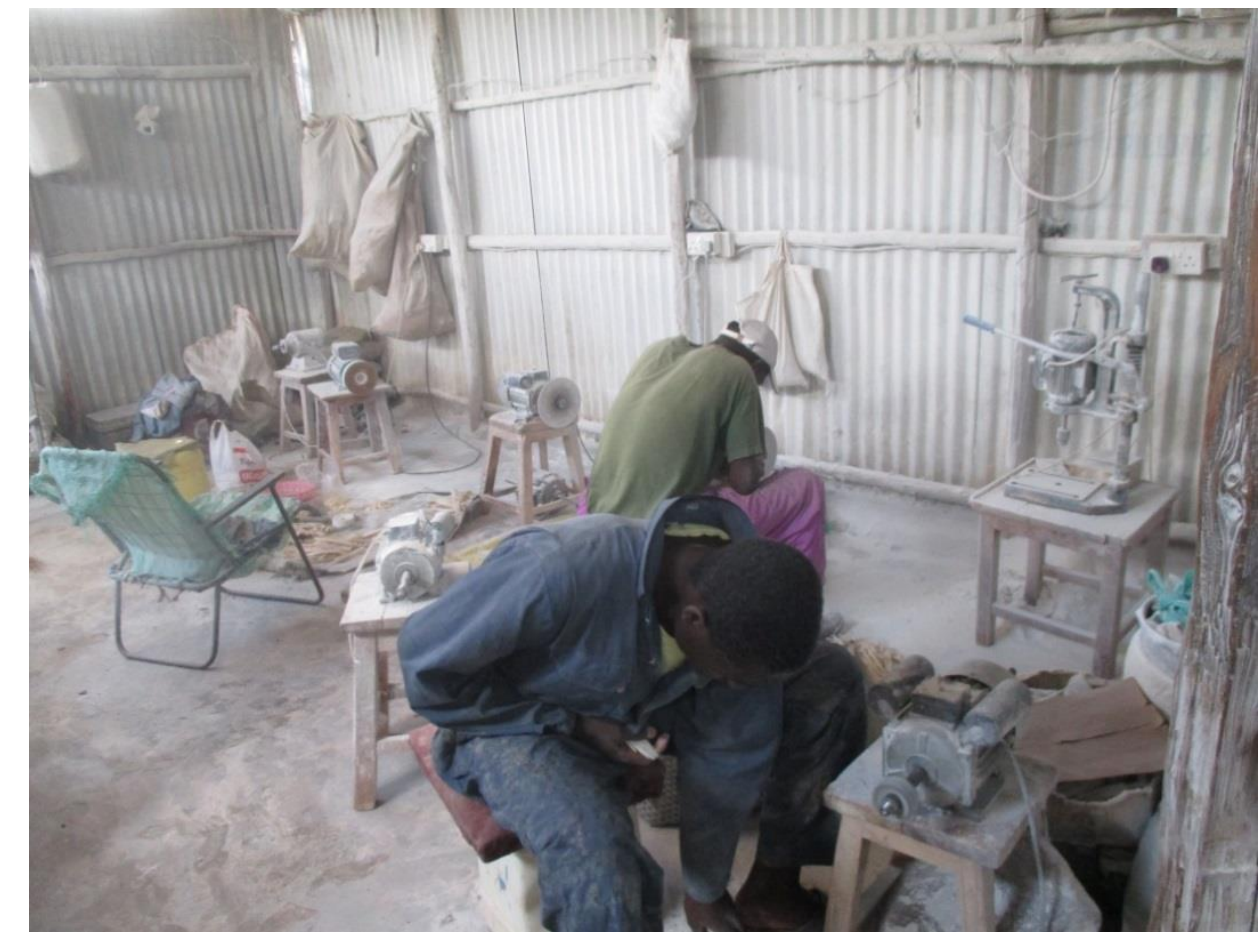

Plate 1. A section of workers working on bones at Victories Brothers workshop. Photo was taken by the authors during field survey in February 2015.

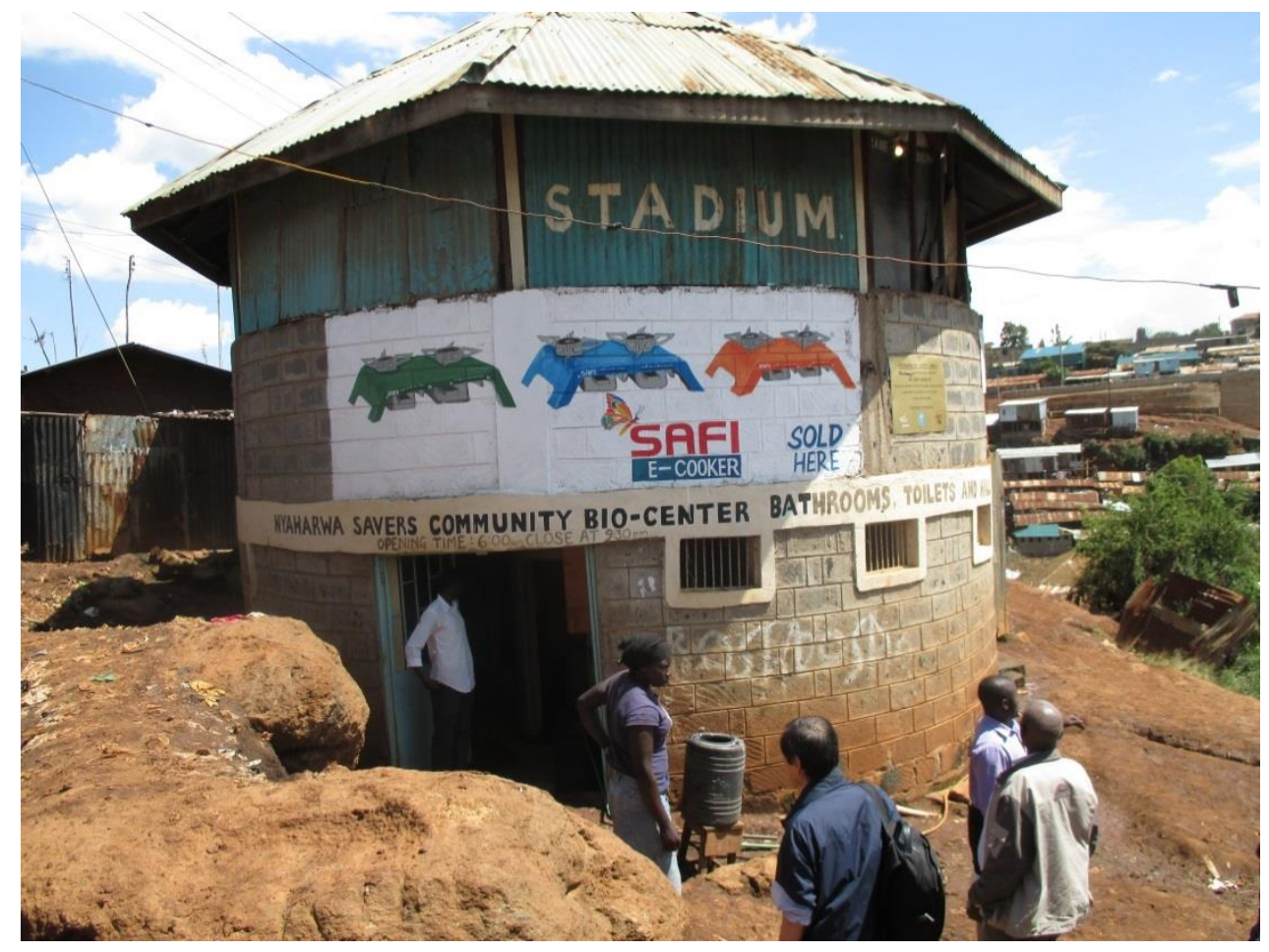

Plate 2. A multi-purpose bio-centre constructed by Umande Trust in Kibera. Photo was taken by authors during field survey in February 2015. 


\subsection{Collective State}

The collective state sub component (Figure 2) is a good proxy of community social capital. Moser (1998) posits that "the extent to which a community itself can be considered an asset that reduces vulnerability or increases opportunities depends on its "stock" of social capital". It is the strongest asset of Kibera residents. Kibera, though informal it may be, is known to be embedded with strong networks which bind the people together. Even though the overall collective state level is medium, there are exceptions with respect to individual indicators. While the level of family ties and group formation is very high, those of trust and crime free environment are medium and low respectively. The results of family ties and group membership are clear indication of interdependency in the community. Interviews with the people revealed that most people were born and bred in the community while others migrated with the aim of finding city jobs in order to live a meaningful life. These people have been serving as transit points and sometimes host families for other relatives coming from the villages. As a result, relations keep expanding serving as safety net for both old and new members. Group formation on the other hand is a major channel by which the people get access to external support be it financial or inkind. In view of this, Kibera currently can boast of more than hundred groups. These groups are based on common interest usually comprising of 8 or more members. For instance, a key requirement by Umande Trust for the allocation of bio-centre in a particular area is a well-organized group that can be entrusted with the management of the facility. Likewise, Taka Ni Pato and Victorious Brothers all started with few individuals with a shared common vision. These groups now have many members and are able to access financial support for their respective business operations. In fact, all the development partners such as the NGO's as well as the government require the people to be in groups in order to be assisted. The main idea behind the group model is that it is a good source of social collateral as it enhances efficiency. Meanwhile, Kibera is not crime free. This result can be attributed to the high level of youth unemployment. Discussions with residents confirmed that most youth due to lack of jobs result to all manner of social vices such as armed robbery, prostitution, drug dealings to mention but a few. The outcome as the result indicates has been the lack of trust among community members. It is therefore no surprise that the level of trust is low in Kibera. This result evidently calls for support for job creation as creating more jobs will reduce the social vices which can in turn restore trust in the community. 


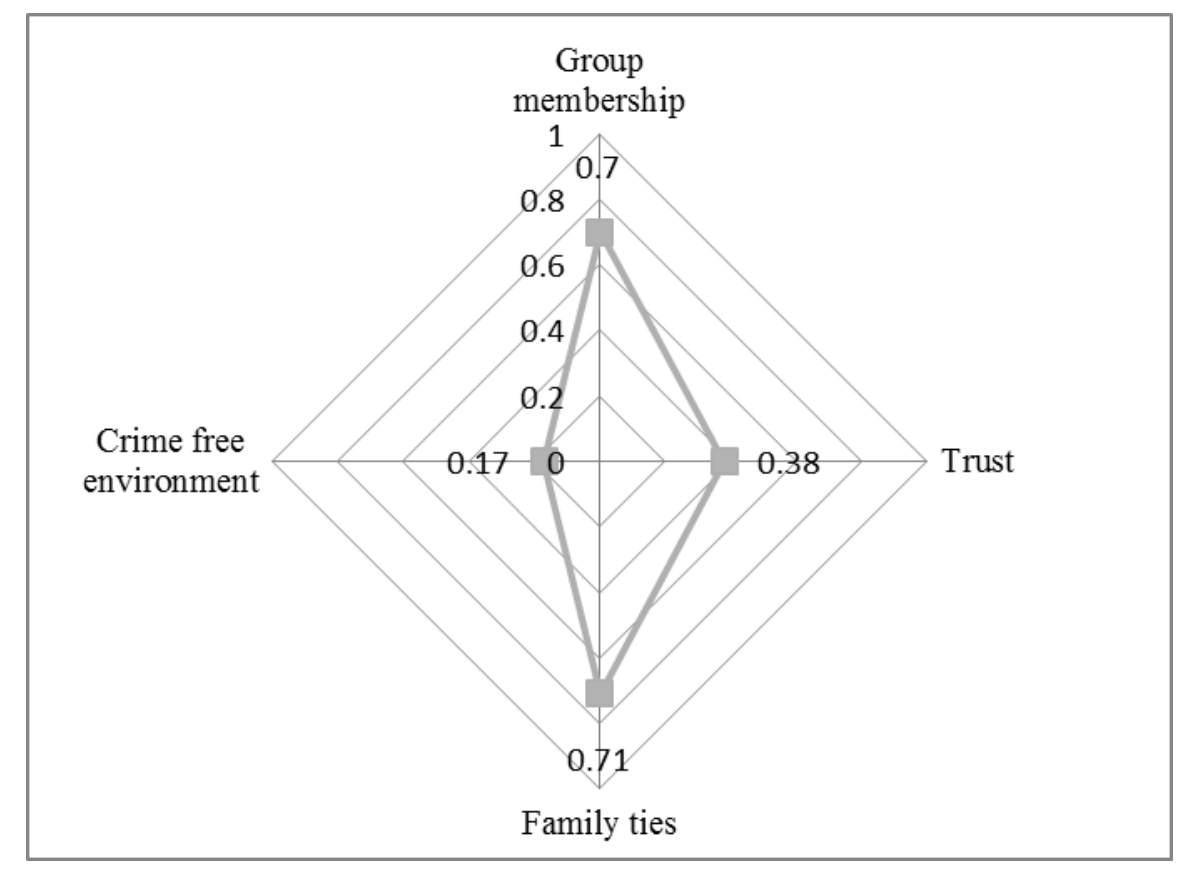

Figure 3. Collective state of people in Kibera

\subsection{Individual Access}

As indicated on Table 2, the level of individual access to critical human needs in Kibera is medium. However, individual indicators are insightful. The high level of food accessibility is a true reflection on the ground. The close proximity to downtown Nairobi where all the major food markets are situated means that residents in Kibera do not struggle to find food. Meanwhile, the sack gardening project- a form of urban agriculture (Plate 3) under the National Youth Service (NYS - an initiative by the government) to create employment for the youth could be cited as a major contributing factor to food accessibility and availability in Kibera. This project encourages residents to grow their own food and sell surpluses for cash. With respect to healthcare, organisations such as MSF and Carolina for Kibera (CFK) are actively involved. MSF- an international humanitarian organization for instance, in May 16, 2013, inaugurated a clinic to offer comprehensive basic healthcare and maternity services to the residents of Kibera for free. Their basic healthcare is integrated with the management of chronic diseases like HIV which is known to be prevalent in Kibera (MSF 2013). Likewise, CFK's Tabitha Clinic is a community-based medical clinic which offers basic healthcare and youth-friendly services to Kibera residents on a small fee. CFK focuses on family planning and reproductive health, HIV/AIDS and primary healthcare. In addition, they target low income earning households, young people aged (13-24) and women (CHMI 2015). Others like Ushirika - a community owned clinic and Tele-Health clinic supported by UN-Habitat are also contributing to healthcare delivery in Kibera. But the result clearly calls for more support for healthcare. Likewise, policy has to pay attention to education and job creation. Improving education would go a long way to help people secure more formal and well paid jobs thereby taking them out of the poverty web. For housing, it still remains a major challenge. Known officially as "Slum", the area is dominated by shacks with no proper drainage systems (Plate 4). Massive upgrading is needed to improve the housing situation. 


\section{Ml Macrothink}

Environmental Management and Sustainable Development

ISSN 2164-7682

2015, Vol. 4, No. 2

But it is warned that any attempt to relocate them might fail just like the KENSUP project which is now occupied by the middle class people. Residents see Kibera as their home and no amount of force can move them out. Relocating them means total destruction of their social networks which took them decades to build. Thus bad policies or acts within a short period of time could have tragic effects on social assets (Shivakoti and Shrestha 2005). This study therefore advocates for sensitization and individual structure upgrading initiatives.

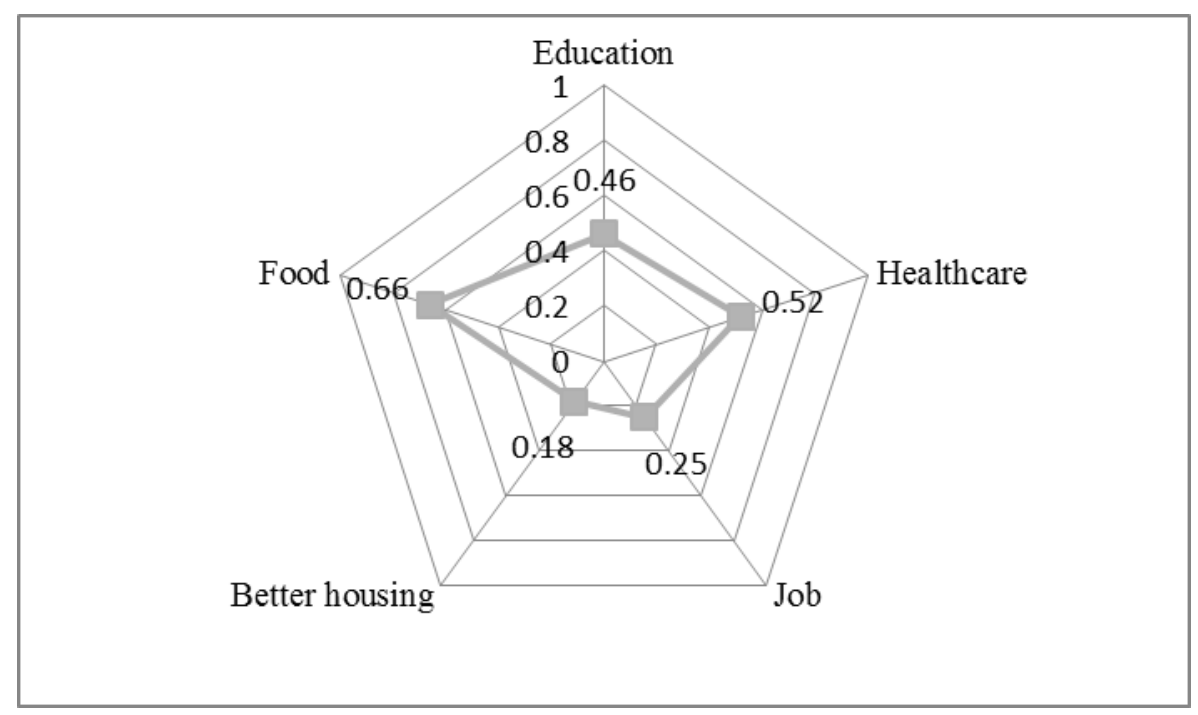

Figure 4. Individual access of people in Kibera

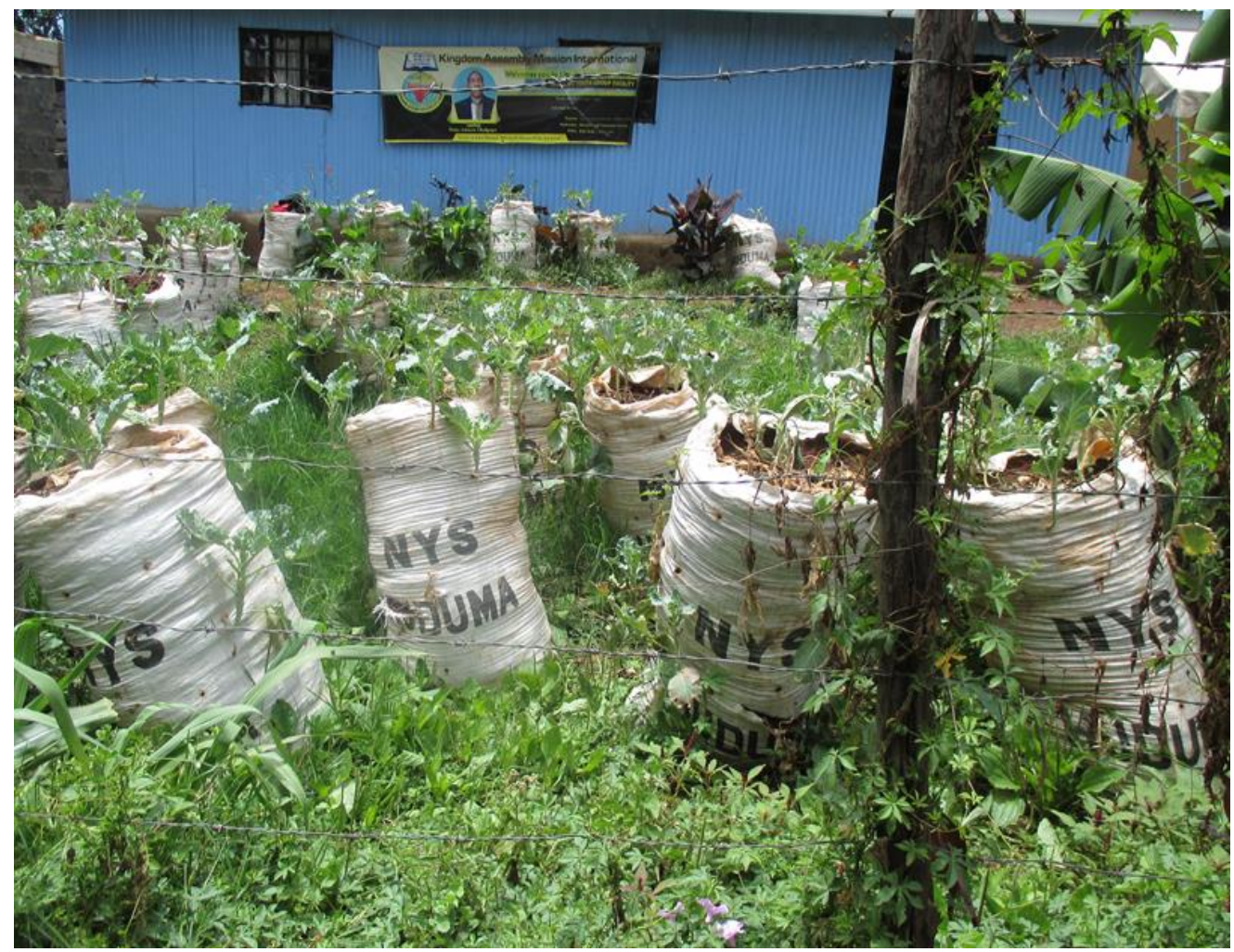

Plate 3. NYS community gardening initiative in Kibera. Photo was taken by the authors during field survey in February 2015. 


\section{Macrothink}

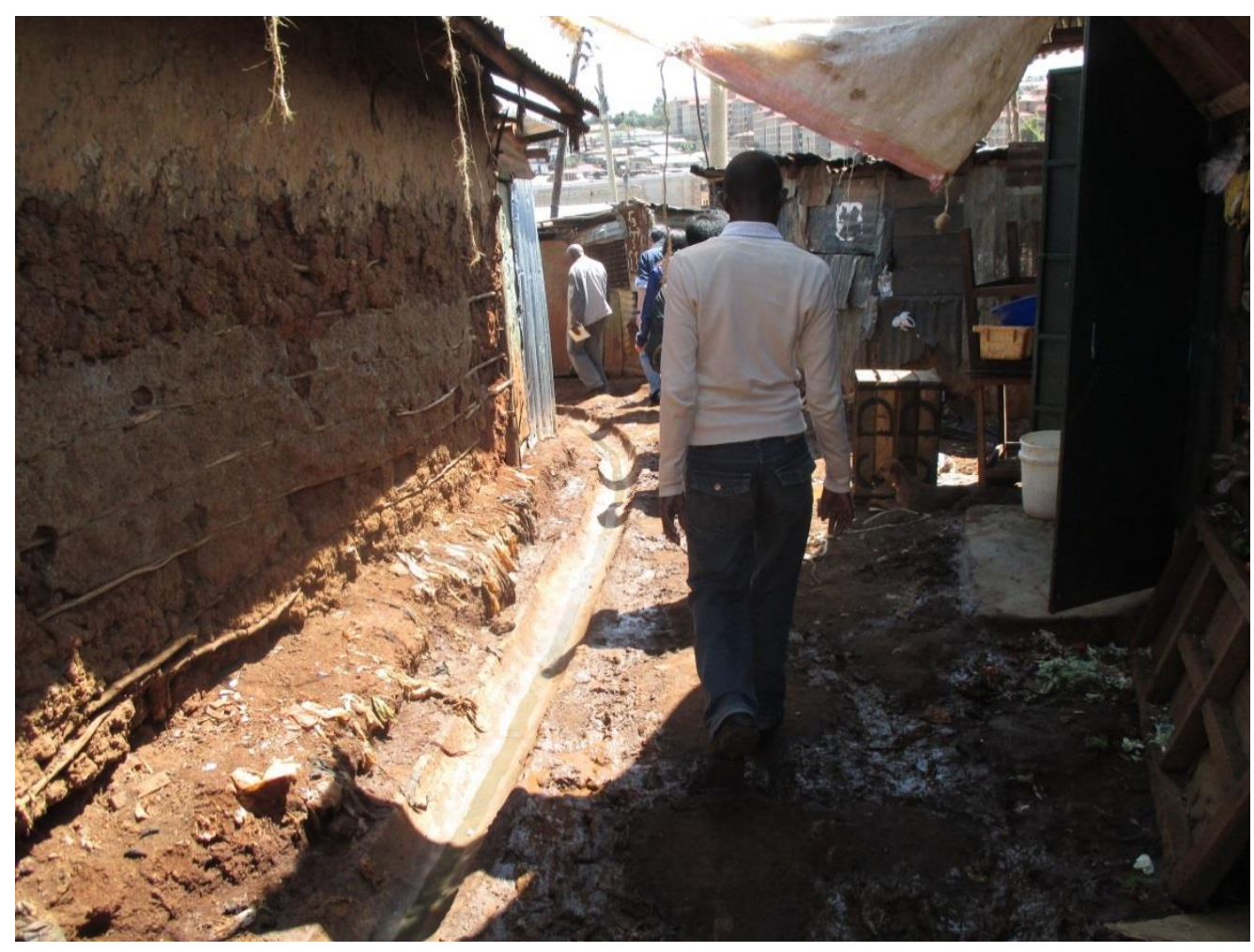

Plate 4. A typical drain and housing structure in Kibera. Photo by authors during survey.

\section{Conclusion}

This paper aimed to review the indicators of social sustainability and empirically apply them. The review shows that the concept defies single definition as it is context specific. Thus, what one community considers crucial to their social sustainability might not apply in different situations. This suggests that the local context is critical in developing or selecting social sustainability indicators. The study identified three broad dimensions of social sustainability; representation mechanism, collective state and individual access with each sub component having specific indicators. Empirical application in Kibera found the level of social sustainability to be medium. The highest contributing sub component was collective state with the least being representation mechanism. Regarding collective state, family ties and group membership recorded the highest score indicating that social capital is the biggest asset of Kibera. The implication of the collective state sub component in the community is that development projects are likely to succeed if implemented especially via the group model. This is because it is relatively easier to seek the consent and cooperation of a group in the course of project formulation and implementation. Robert Putnam's (1993) often cited definition says that social capital are the attributes of social organization e.g. networks and norms which has the potential of improving the efficiency of society by facilitating coordinated actions. Lin et al. (2001) stressed that social capital is a special resource which is usually mobilized to aid in purposeful development actions. The study results indicated the need for policy support for inclusive governance and creation and improvement in critical human needs such as better housing, job, security, education and community trust. Addressing these diverse issues would be critical in enhancing social sustainability level in 
Kibera.

This study has uniquely given meaning to social sustainability. However, other techniques such as Fuzzy Logic and AHP can be used to validate the current approach.

\section{Acknowledgement}

The empirical data collection was financially supported by the Ministry of Education, Culture, Sports, Science and Technology (MEX) of Japan through the Grant-in-Aid Program for Leading Graduate Schools "Graduate Program in Sustainability Science - Global Leadership Initiative (GPSS-GLI)" of the University of Tokyo.

\section{References}

Agyeman, J., R. Bullard, \& B. Evans (Eds.). (2003). Just Sustainability: Development in an Unequal World. London: Earthscan/MIT Press, London.

Agyeman, J., \& Evans, B. (2004). Just sustainability: the emerging discourse of environmental justice in Britain? The Geographical Journal, 170(2), 155-164. http://doi/10.1111/j.0016-7398.2004.00117

Agyeman, J. (2008). Toward a "Just" sustainability? Continuum: Journal of Media \& Cultural Studies, 22(6), 751-756.

Axelsson, R, Angelstam, P., Degerman, E., Teitelbaum, S., Andersson, K., Elbakidze, M., Drotz, K. M. (2013). Social and Cultural Sustainability: Criteria, Indicators, Verifier Variables for Measurement and Map for Visualization. AMBIO, 42, 215-228. http://doi:10.1007/s13280-012-0376-0

Bostrom, M. (2012). A missing pillar? Challenges in theorizing and practising social sustainability: introduction to the special issue. Sustainability: Science, Practice and Policy, 8(1), 3-14. http://www.google.com/archives/vol8iss1/introduction.bostrom.html

Boström, M. (2011). The problematic social dimension of sustainable development: the case of the Forest Stewardship Council. International Journal of Sustainable Development \& World Ecology 19(1), 3-15. http://dx.doi.org/10.1080/13504509.2011.582891

Chambers, R., \& Conway, R. G. (1991). Sustainable rural livelihoods: practical concepts for the $21^{\text {st }}$ century. IDS Discussion Paper 296.

Chen, H., Zhu, T., Krott, M., Calvo, F. J, Ganesh, P. S., \& Makoto, I. (2013). Measurement and evaluation of livelihood assets in sustainable forest commons governance. Land Use Policy 30, 908-914.http://dx.doi.org/10.1016/j.landusepol.2012.06.009

Cronin, V., \& Gutherine, P. (2011). Alternative approaches to slum upgrading in Kiberia, Nairobi. Urban Design and Planning, Vol. 164 Issue DP2.

Chan, E., \& Lee, K. (2008). Critical factors for improving social sustainability of urban renewal projects. Social Indicators Research, 85(2), 243-256. http://doi:10.1007/s11205-007-9089-3 


\section{Macrothink}

Environmental Management and Sustainable Development

ISSN 2164-7682

2015, Vol. 4, No. 2

Cuthill, M. (2009). Strengthening the "social" in sustainable development: developing a conceptual framework for social sustainability in a rapid urban growth region in Australia. Sustainable Development, 18(6), 362-373.http://doi:10.1002/sd.397

Costanza, R., Norton, B.m \& Haskell, B. D. (1992). Ecosystem health: New Goals for Environmental Management, Island Press Washington, D.C., USA

Centre for Health Market Innovations (CHMI) (2015). Carolina for Kibera. Accessed on august 2, 2015 at http://healthmarketinnovations.org/program/carolina-kibera-cfk

Dempsey, N., Bramley, G., Powers, S., \& Brown, C. (2011). The social dimension of sustainable development: defining urban social sustainability. Sustainable Development, 19(5), 289-300.http://doi:10.1002/sd.417

Dobson, A. (Ed.). (1999). Fairness and Futurity: Essays on Environmental Sustainability and Social Justice. New York: Oxford University Press.

Dixon, T., \& Colantonio, A. (2008). Submission to EIB Consultation on the Draft EIB Statement of Environmental and Social Principles and Standards. Oxford: Oxford Institute for Sustainable Development

Dillard, J., Dujon, V., \& King, M. (Eds.). (2009). Understanding the Social Dimension of Sustainability. New York: Routledge.

Davidson, M. (2009). Social sustainability: a potential for politics? Local Environment, 14(7), 607-619. http://dx.doi.org/10.1080/13549830903089291

French Institute for Research in Africa (IFRA) and Keyobs (2009). Map

Goodland, R. (2002). Sustainability: human, social, economic and environmental. In T. Munn (Ed), Encyclopedia of Global Environmental Change. 488-489. Hoboken, NJ: Wiley.

Hans-Boeckler-Foundation (Ed.) (2001), Pathways towards a sustainable future, Setzkasten, Düsseldorf.

Huzayyin, S., \& Salem, H. (2013). Analysis of thirty years evolution of urban growth, transport demand and supply, energy consumption, greenhouse and pollutants emissions in Greater Cairo. Research in Transportation Economics, 40(1), 104-115

Higgins, A. (2013). Why residents of Kibera slum are rejecting new housing plans. [Online] Avilable:http://www.one.org/international/blog/why-residents-of-kibera-slum-are-rejecting-n ew-housing-plans/ (November 25, 2014)

Klooster, D. (2010). Standardizing sustainable development? The Forest Stewardship Council's plantation policy review pro-cess as neoliberal environmental governance Geoforum, 41(1), 117-129.http:// doi:10.1016/j.geoforum.2009.02.006

Kibera UK-The Gap Year Company (2007). [Online] Available: http://www.kibera.org.uk/Facts.html (November 25, 2014).

Kaiganaine, J. (2009). Interview with Kensup manager. UN-Habitat. Nairobi, Kenya 
Littig, B. and Grießler, E. (2005). Social sustainability: a catchword between political pragmatism and social theory. International Journal of Sustainable Development, 8(1-2), 65-79.

Lehtonen, M. (2004). The environmental-social interface of sustainable development: capabilities, social capital, institutions. Ecological Economics, 49(2), 199-214.http:// doi:10.1016/j.ecolecon.2004.03.019

Lin, N., Cook, K.S., Burt, R.S., (2001). Social Capital: Theory and Research. Aldine de

Littig, B. (2001), Zur sozialen Dimension nachhaltiger Entwicklung, Strategy Group Sustainability.

Mancini, F., Termorshuizen, A., Jiggins, J., and van Bruggen, A. (2008). Increasing the environmental and social sustainability of cotton farming through farmer education in Andhra Pradesh, India. Agricultural Systems, $\quad 96(1-3), \quad$ 16-25. http://dx.doi.org/10.1016/j.agsy.2007.05.001

Maheshwari, P., Khaddar, R., Kachroo, P., \& Paz, A. (2014). Dynamic Modeling of Performance Indices for the Planning of Sustainable Transportation Systems. Networks and Spatial Economics, DOI: 10.1007/s11067-014-9238

Murphy, K. (2012). The social pillar of sustainable development: a literature review and framework for policy analysis. Sustainablity: Science, Practice and Policy, 8(1), 15-29. http://www.google.com/archives/vol8iss1/1008-041.murphy.html

Moser, O. N. C. (1998). The Asset Vulnerability Framework: Reassessing Urban Poverty Reduction Strategies. World Development, 26(1), 1-19.

Miller, A. C. (2004). "New Civic Epistemologies of Quantification: Making Sense of Local and Global Indicators of Sustainability," Science, Technology \& Human Values, 30(3), 403-432

Miller, A. C. (2007). Creating indicators of sustainability; A social approach. International Institute for Sustainable Development (IISD) Discussion Paper.

Magis, K., \& Shinn, C. (2009). Emergent principles of social sustain-ability. In J. Dillard, V. Dujon, \& M. King (Eds.), Understanding the Social Dimension of Sustainability. pp. 15-44. New York: Routledge.

MSF (2013). Kenya: New clinic brings comprehensive case to most vulnerable. [Online] Available:http://www.msf.org/article/kenya-new-clinic-brings-comprehensive-care-most-vuln erable( August 2,2015)

“Social”. Merriam-Webster.com (2012). Available: http://www.merriam-webster.com ( May 8, 2015).

Nordström Källström, H. and Ljung, M. (2005). Social sustainability and collaborative learning. Ambio, 34(4-5), 376-382. http://DOI:10.1579/0044-7447-34.4.376

OECD (2001a). The Well-being of Nations. The role of human and social capital, OECD, Paris.

OECD (Ed.) (2001b). Analytic Report on Sustainable Development SG/SD(2001)1-14, OECD, Paris. 
People of Kibera (2010) Kibera Overview [Online] Available: http://www.peopleofkibera.com/kibera/ for further details (November 21, 2014)

Putnam, R. (1993). Making democracy work: civic traditions in modern Italy. Princeton University Press, Princeton.

Paz, A., Maheshwari, P., Kachroo, P., and Ahmad, S. (2013). Estimation of Performance Indices for the Planning of Sustainable Transportation Systems. Advances in Fuzzy Systems. http://dx.doi.org/10.1155/2013/601468.

Rothstein, B., \& E. M. Uslaner. (2005). All for all: Equality, corruption, and social trust. World Politics, 58, 41-72. http://doi:10.1353/wp.2006.0022

ReliefWeb (2010) Kenya: Food Security Emergency in Nairobi Slums Threatens Four Million [Online] Available: http://www.reliefweb.int/rw/rwb.nsf/db900sid/MYAI-7TF6ZV?OpenDocument for further details (November 21, 2014)

Scoones, I. (2007). Sustainability. Development in Practice, 17(4-5), 589-596.http:// doi: $10.1080 / 09614520701469609$

Spangenberg, J. H. (2002), Development of Institutional Sustainability Indicators, Sustainable Development Vol. 10(2), 103-115. http://doi:10.1002/sd.184

Spangenberg, J. H. and Omann, I. (2002), Assessing social sustainability: The social dimension of sustainability in a socio-economic scenario, A paper presented at the $7^{\text {th }}$ Biennial Conference of the International Society for Ecological Economics in Sousse, Tunisia, 6 - 9 March 2002.

Schlossberg, M., \& Zimmerman, A. (2003). Developing statewide indices of environmental, economic, and social sustainability: a look at Oregon and the Oregon benchmarks. Local Environment, 8(6), 641-660.http://doi:10.1080/762742062

Shivakoti, G., \&Shrestha, S. (2005). Analysis of livelihood asset pentagon to assess the performance of irrigation systems. Water International, 30(3), 356-362. http:// doi:10.1080/02508060508691876

Shreck, A., Getz, C., \& Feenstra, G. (2006). Social sustainability, farm labor, and organic agriculture: findings from an exploratory analysis. Agriculture and Human Values, 23(4), 439-449. http://doi 10.1007/s10460-006-9016-2

Taylor, P. (2004). In the market but not of it: fair trade coffee and Forest Stewardship Council certification as market-based social change. World Development, 33(1), 129-147. http:// doi:10.1016/j.worlddev.2004.07.007

United Nations Commission for Sustainable Development (UNCSD). (1996). Indicators for Sustainable Development, Framework and Methodology [Online] Available: http://esl.jrc.it/envind/un_meths/UN_ME_c.htm. (January 29, 2012)

United Nations Department of Social and Economic Affairs (UNDESA) (2001). Indicators of 
Sustainable Development: Framework and Methodologies. New York: United Nations.

Turkington, R., \& Sangster, K. (2006). From housing to social mix: housing's contribution to social sustainability. Town and Country Planning, 75(6), 184-185.

Umande Trust 2014. Bio-centres innovations [Online] Available: http//.www.umande.org/bio-centre-innovation/ (July 30, 2015)

Vifell, C. A., \& Soneryd, L. (2012). Organizing matters: how "the social dimension" gets lost in sustainability projects. Sustainable Development Vol. 20(1), 18-27.http://doi:10.1002/sd.461

World Commission on Environment and Development. (1987a). Our Common Future: Report of the World Commission on Environment and Development, Oxford: Oxford University Press.

\section{Copyright Disclaimer}

Copyright for this article is retained by the author(s), with first publication rights granted to the journal.

This is an open-access article distributed under the terms and conditions of the Creative Commons Attribution license (http://creativecommons.org/licenses/by/3.0/). 